\title{
CIÊNCIA LENTA E ÉTICA NA PESQUISA
}

Vos últimos meses de 2011, duas notícias circularam pelos mídias certo modo, elas estavam inter-relacionadas. Ambas, além disso, tinham ligação direta com a política editorial dos periódicos científicos, pelo que aqui as comentamos.

A primeira notícia consistia na divulgação de um documento elaborado pelo CNPq sobre ética na pesquisa. Mais especificamente, tratava-se de diretrizes para promover a ética na publicação de pesquisas, visando o estabelecimento de parâmetros para apurar condutas reprováveis. Entre as recomendações, consta a de assinalar claramente o uso de trabalhos já divulgados e a de não fragmentar resultados de um único estudo em diferentes publicações, privilegiando, ao invés disso, sua apresentação como um "todo coesivo".

Tais recomendações têm implicações óbvias, tanto para a realização das pesquisas, quanto para as suas dinâmicas de divulgação. A pressão pelo aumento do número de artigos a serem publicados, bem como a própria tendência de se avolumarem o número de títulos disponíveis, faz com que editores recebam uma enxurrada crescente de trabalhos a serem avaliados. Uma quantidade significativa desses trabalhos mostra-se claramente elaborada às pressas e, por vezes, sem condições de cumprir quesitos mínimos de cientificidade.

A segunda notícia dizia respeito à divulgação do slow sciense movement, iniciativa deflagrada por um grupo de pesquisadores alemães, mas com pretensões internacionais, que visa questionar a aceleração da realização de pesquisas. De acordo com o manifesto do movimento, a ciência não se desenvolve com movimentos bruscos, mas sim se arrastando numa escala de tempo muito lenta. A ciência, nesse sentido, continua o manifesto, precisa de tempo: "tempo para pensar, ler e falhar" (http://slow-science.org/).

O pesquisador e jornalista científico John Horgan comentou a iniciativa no blog da Scientific American. Ironicamente, ele recomendou o extermínio do movimento da ciência lenta. Destacando que boa parte da sua carreira dedicava-se a denunciar más práticas científicas, Horgan dizia temer não ter mais assuntos a tratar caso os cientistas começassem a publicar apenas dados e teorias de alta qualidade, checados duas ou três vezes antes de serem apresentados aos periódicos. 
De fato, tudo isso sublinha a urgente necessidade da comunidade científica dedicar mais atenção aos mecanismos que operam no processo de veiculação de resultados de pesquisas. A intensificação de condutas antiéticas em ambientes de pesquisa é um dos resultados da atual corrida pela publicação, onde a ânsia por nome fama e prestígio tornou-se objeto de disputa por si só, de forma quase independente de seus conteúdos ou contribuições específicas. O fascínio pelo número, pela pontuação, pode estar substituindo o papel fundamental da socialização do conhecimento. Tal fascínio, alimentado pelas atuais diretrizes da política científica, vem constituindo-se numa espécie de círculo vicioso que precisa ser mais bem avaliado em seus desdobramentos para a atividade científica e para a sociedade.

A cautela no processo de divulgação de resultados por parte dos pesquisadores, e metas menos megalomaníacas por parte das agências de fomento seriam duas posturas igualmente bem-vindas. Com certeza, muitos editores agradeceriam.

Cleber Dias

Ana Márcia Silva

Editores 